\title{
Preliminary report on use of depot formulation of LHRH analogue ICI 118630 (Zoladex) in patients with prostatic cancer
}

\author{
S R AHMED, J GRANT, S M SHALET, A HOWELL，S D CHOWDHURY, T WEATHERSON, \\ N J BLACKLOCK
}

\begin{abstract}
A study was conducted of the response of the pituitarytesticular axis to two different methods of administration of the luteinising hormone releasing hormone (LHRH) analogue ICI 118630 (Zoladex) in patients with prostatic cancer. The analogue was given by continuous infusion to four previously untreated patients with prostatic cancer for 60 days (group 1). Subsequently a further four patients were given a depot formulation of the same analogue by subcutaneous injection once every 28 days (group 2). Both methods of administration produced similar, successful suppression of luteinising hormone (LH) associated with a reduction of testosterone to castrate concentrations.

The median basal testosterone concentrations before treatment in groups 1 and 2 were 20.6 and $14 \cdot 1 \mathrm{nmol} / 1$ $(5.94$ and $4.07 \mathrm{ng} / \mathrm{ml})$ respectively; these were reduced to 1.4 and $1.1 \mathrm{nmol} / 1(0.40$ and $0.32 \mathrm{ng} / \mathrm{ml})$ within four weeks of the start of treatment. The median basal LH concentration in groups 1 and 2 were 7.9 and $16.6 \mathrm{IU} / 1$ respectively, which were suppressed to 2.6 and $2.4 \mathrm{IU} / 1$ by four weeks. The suppression of $L H$ and testosterone was maintained with continuous subcutaneous infusion for up to 60 days in group 1 , and by subsequent injections of the depot every 28 days in group 2.
\end{abstract}

\footnotetext{
University Hospitals of South Manchester

S R AHMED, MD, MRCP, registrar, department of endocrinology

J GRANT, FRCS, senior registrar, department of urology

S M SHALET, MD, FRCP, consultant endocrinologist

A HOWELL, MRCP, senior lecturer and consultant, department of medical oncology

S D CHOWDHURY, FRCS, senior lecturer, department of urology

T WEATHERSON, BSC, research sister, department of urology

N J BLACKLOCK, FRCS, professor of urology

Correspondence to: Dr S M Shalet, Department of Endocrinology, Christie Hospital and Holt Radium Institute, Withington, Manchester M20 9BX.
}

The use of a depot preparation of an LHRH analogue to suppress gonadotrophin and sex hormone secretion offers the convenience of once monthly injections when LHRH analogues are required for the long term treatment of elderly patients with prostatic cancer and children with precocious puberty.

\section{Introduction}

Analogues of luteinising hormone releasing hormone (LHRH) are being used increasingly in the treatment of hormone dependent cancers ${ }^{1-4}$ and precocious puberty ${ }^{56}$ and have potential use in contraception.? We and others have reported on the successful medical castration achieved with the LHRH analogue ICI 118630 (Zoladex) in patients with prostatic cancer and on the therapeutic efficacy of this new hormonal treatment in these patients. ${ }^{1}{ }^{2} 8$ This treatment, however, has the practical disadvantage of requiring administration of daily subcutaneous injections of the drug for prolonged periods in elderly patients. Recently a biodegradable lactide copolymer has been developed which allows continuous, sustained release of incorporated polypeptide, and this has led to the development of a depot formulation of ICI $118630 .{ }^{9}$ We present a preliminary report on the successful use of the depot preparation of this LHRH analogue in patients with prostatic cancer.

\section{Patients and methods}

We first studied the effect of continuous subcutaneous infusion of the standard solution formulation of ICI 118630 using an MS16A syringe driver (Graseby Dynamics). Four previously untreated patients, aged 67-85 years, with advanced metastatic prostatic cancer, who were relatively free of symptoms were included in the study. All four patients received $120 \mu \mathrm{g}$ of the standard formulation daily by continuous subcutaneous infusion for 60 days. The subcutaneous cannula was sited in the anterior abdominal wall, protected by a gauze dressing, and resited every three or four days. The pump was carried in a shoulder holster strapped unobtrusively beneath clothing. 
In the second part of the investigation we studied four different patients, aged 64-73, with advanced metastatic prostatic cancer that was also previously untreated and relatively asymptomatic. These four patients were treated with the depot formulation of the analogue. This is prepared as a biodegradable implant in which the LHRH analogue is incorporated in a matrix of a lactide-glycolide copolymer.

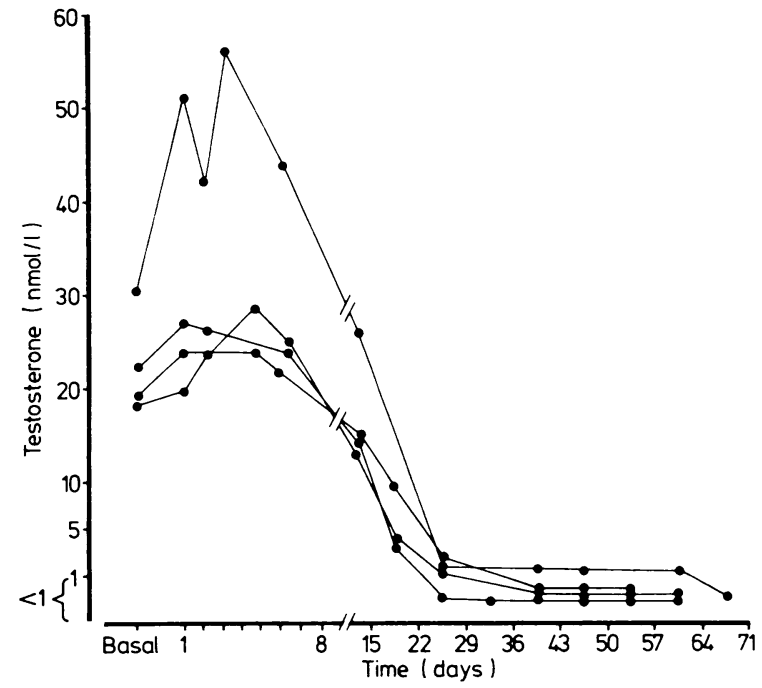

FIG 1 -Testosterone concentrations in group 1.

Conversion: SI to traditional units-Testosterone: $1 \mathrm{nmol} / \approx$ $0.29 \mathrm{ng} / \mathrm{ml}$.



FIG 2-Luteinising hormone ( $\mathrm{LH}$ ) concentrations in group 1

The copolymer drug carrier substance is similar to absorbable suture material and when placed subcutaneously biodegrades completely to lactic and glycolic acids. As the matrix biodegrades the embedded LHRH analogue is released into the subcutaneous tissue and absorbed into the systemic circulation. The implant consists of a cylindrical rod $1.2 \mathrm{~mm}$ diameter; the length is proportional to the dose, a $6 \mathrm{~mm}$ rod containing approximately $1 \mathrm{mg}$ of analogue. Animal and in vitro studies show that ICI 118630 is released continuously from the lactide-glycolide copolymer for up to 30 days. The copolymer carrier substance is completely biodegradable and no material is recoverable from the site of the subcutaneous injection after about five weeks. ${ }^{10} 11$

As part of a larger dose response study the patients were randomised to receive one of three doses $(0.9 \mathrm{mg}, 1.8 \mathrm{mg}$, and $3.6 \mathrm{mg})$ of the depot formulation of the analogue. The three different doses of the depot release approximately $30 \mu \mathrm{g}, 60 \mu \mathrm{g}$, and $120 \mu \mathrm{g}$ of analogue respectively over 24 hours and continue to do this for at least 28 days. The depot is placed in the subcutaneous tissue of the anterior ab- dominal wall through a size 16 hypodermic needle after the injection $\frac{\text { o }}{-}$ site has been infiltrated with local anaesthetic. Patients received an $\checkmark$ injection of the depot every 28 days. Basal testosterone and gonadotrophin concentrations were estimated before the start of treatment $c$ and on days $1,2,3,4,5,8,11$, and 15 and at weekly intervals there- $\widehat{\Omega}$ after in all patients. An LHRH stimulation test, measuring serum follicle stimulating hormone $(\mathrm{FSH})$ and luteinising hormone ( $\mathrm{LH})$ concentrations before and 20 and 60 minutes after administration of $\mathbb{D}$ $100 \mu \mathrm{g} \mathrm{LHRH}$ intravenously, was done before treatment in all patients and before every depot injection in patients in group 2 and 2 on days 11 and 18 of the subcutaneous infusion in patients in group 1. Routine haematological and biochemical values were also monitored $\overline{\bar{\omega}}$ periodically. Testosterone concentration was measured by radio- $\overrightarrow{0}$ immunoassay after celite column chromatography. ${ }^{12}$ FSH and $\mathrm{LH}$ concentrations were measured by specific radioimmunoassay. ${ }^{13}$

\section{Results}

In the four patients who received a continuous infusion of the analogue the median basal testosterone concentration before treat- $\vec{\omega}$ ment was 20.6 (range $18 \cdot 0-30 \cdot 0) \mathrm{nmol} / 1(5 \cdot 94(5 \cdot 19-8 \cdot 65) \mathrm{ng} / \mathrm{ml})$. By O the fourth week of the infusion this was reduced to a castrate value $\frac{\mathrm{O}}{3}$ of $1 \cdot 4(0 \cdot 6-2 \cdot 6) \mathrm{nmol} / \mathrm{l}(0 \cdot 40(0 \cdot 17-0 \cdot 75) \mathrm{ng} / \mathrm{ml})$ (fig 1). The median basal LH concentration was $7.9(3.8-36.0)$ IU/l before treatment, and this was suppressed to $2 \cdot 6(2 \cdot 2-3 \cdot 4)$ IU/l by four weeks (fig 2). Both the LH and testosterone concentrations showed an initial rise during the first week of the infusion.

In the four patients who received the depot injection (group 2) $\vec{\circ}$ the $\mathrm{LH}$ and testosterone concentrations were similarly suppressed by o four weeks, after an initial rise during the first week (figs 3 and 4). 응 The median basal $\mathrm{LH}$ and testosterone concentrations before treatment were $16 \cdot 0(6 \cdot 6-53 \cdot 0) \mathrm{IU} / 1$ and $14 \cdot 1(11 \cdot 0-17 \cdot 5) \mathrm{nmol} / 1(4 \cdot 07(3 \cdot 17-\overrightarrow{0}$ $5.05) \mathrm{ng} / \mathrm{ml}$ ) respectively. Four weeks after the first depot injection the values were $2 \cdot 45(2 \cdot 3-4 \cdot 4) \mathrm{IU} / 1$ and $1 \cdot 1(0 \cdot 7-1 \cdot 7) \mathrm{nmol} / 1(0 \cdot 32(0 \cdot 20-5$ $0.49) \mathrm{ng} / \mathrm{ml}$ ) respectively. This suppression was maintained with subsequent depot injections (figs 3 and 4).

The acute $\mathrm{LH}$ response to gonadotrophin releasing hormone was abolished by four weeks of treatment in both groups of patients. The median increments of LH from basal values were $22.7(17 \cdot 0$ $38.0) \mathrm{IU} / 1$ and $28.5(15.0->61.0) \mathrm{IU} / 1$ in groups 1 and 2 respectively, before treatment. These were reduced to $0.25(0-1 \cdot 8) \mathrm{IU} / 1$ and 0.2 $(0-0 \cdot 8) \mathrm{IU} / 1$ by four weeks.

The rise in testosterone concentrations during the first week of treatment was associated with exacerbation of bone pain in one of the $\mathbb{D}$ patients. There was no adverse reaction to the depot injection, either locally or systemically, in any patient.

\section{Discussion}

These preliminary findings show that in patients with prostatic cancer administration of the depot formulation of the LHRH analogue ICI 118630 produces suppression of $\mathrm{LH}$ and consequent reduction of testosterone to castrate concentrations. $\delta$

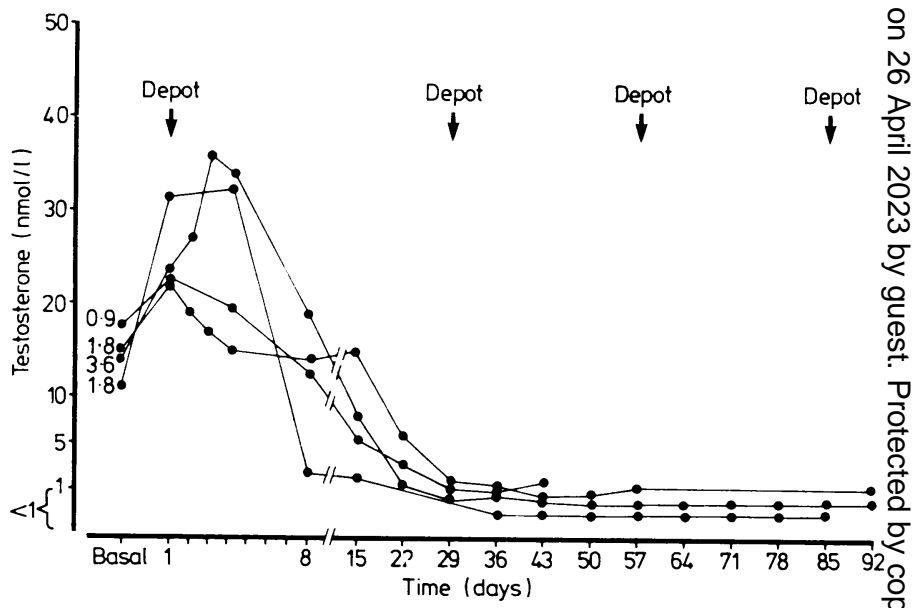

FIG 3-Testosterone concentrations in group 2. Individual dose of depot $(\mathrm{mg})$ received by each patient indicated.

Conversion: SI to traditional units-Testosterone: $1 \mathrm{nmol} / 1 \approx 0.29 \mathrm{ng} / \mathrm{ml}$. 
Adequate suppression of both $\mathrm{LH}$ and testosterone is achieved by four weeks after the first depot injection and is maintained by subsequent injections every 28 days. The hormone profiles in these patients were very similar to those observed in patients who received continuous subcutaneous infusion of the LHRH analogue. Measurements of actual concentrations of the analogue in the circulation, using a specific radioimmunoassay, showed gradually increasing drug concentrations, reaching a peak value at around day 15 after the depot injection, followed by a slow decline to readily detectable concentrations by day $30^{13 a}$ (R N Clayton, personal communication).

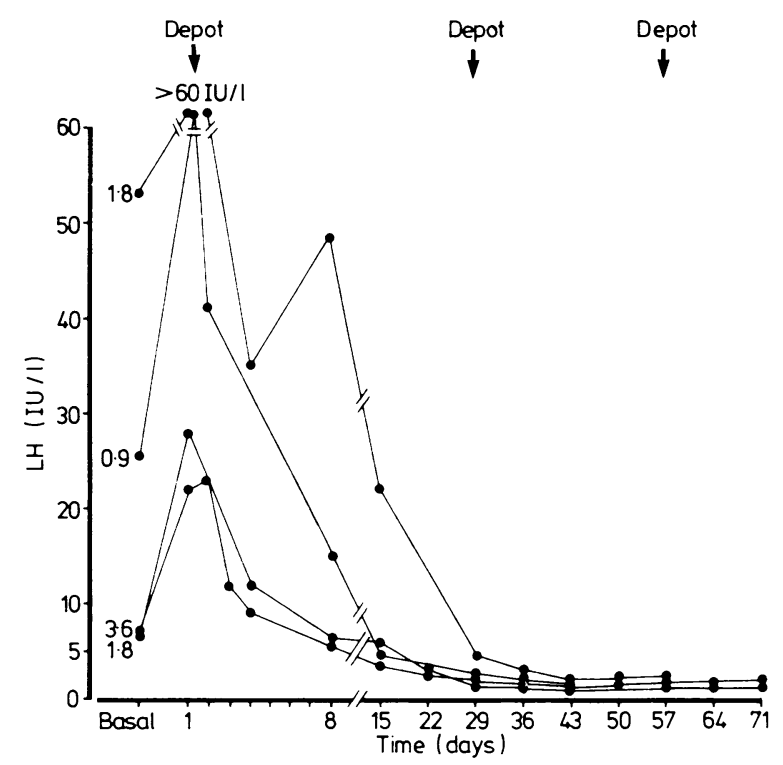

FIG 4-Luteinising hormone ( $\mathrm{LH})$ concentrations in group 2. Individual dose of depot $(\mathrm{mg})$ received by each patient indicated.

During the first week after the first depot injections the $\mathrm{LH}$ and testosterone concentrations increased. A similar rise was also seen during the first week of the continuous subcutaneous infusion. This initial rise is similar to that reported in patients receiving daily injections of the $\mathrm{LHRH}$ analogue. ${ }^{2}$ This initial stimulation of the pituitary-testicular axis, however, is followed by progressive suppression of pituitary $\mathrm{LH}$ secretion and blunting of the $\mathrm{LH}$ response to gonadotrophin releasing hormone, with progressive reduction of testosterone to castrate concentrations. Except in one patient, whose bone pain became worse, the transient rise in androgen concentrations was not associated with any clinical or biochemical exacerbation of the disease.

The paradoxical inhibitory effect of potent agonist LHRH analogues on pituitary-gonadal function has been well documented in animals and man. ${ }^{1}: 1415$ Long term administration of these analogues by daily injection is still, however, associated with acute increases of gonadotrophin and testosterone concentrations. ${ }^{16} 1$; This would be undesirable in patients who are being treated with an LHRH analogue in order to achieve medical castration; more recently there has been a report of failure of persistent suppression of $\mathrm{LH}$ and testosterone values in men treated for prostatic cancer with daily injections of LHRH analogue. ${ }^{18}$

It has been suggested from animal studies that administration of the LHRH analogue by continuous subcutaneous infusion or by continuous release from a subcutaneous depot source, to maintain relatively constant concentrations of the analogue, would be the ideal method of giving the drug to achieve successful, persistent pituitary down regulation and desensitisation. ${ }^{19} 20$ This method of administration of the analogue in patients should overcome the problem of failure of long term suppression that has been observed with daily injections. Our study shows that administration of a depot formulation of the LHRH analogue ICI 118630 produces persistent suppression of LH and testosterone for up to eight weeks.

The availability of a convenient, once monthly injection of an LHRH analogue that successfully suppresses gonadotrophin and sex hormone secretion makes the long term treatment of prostatic cancer in the elderly and of precocious puberty in children a more practicable proposition.

This work was supported by a grant from the Cancer Research Campaign. We thank Mrs M A Green for typing the manuscript.

\section{References}

1 Ahmed SR, Brooman PJC, Shalet SM, Howell A, Blacklock NJ. Treatment of advanced prostatic cancer with LHRH-analogue ICI 118630: clinical response

2 Allen JM, O'Shea JP, Mashiter K, Williams GR, Bloom SR. Advanced carcinoma of the prostate: treatment with gonadotrophin releasing hormone

3 Waxman JH, Wass JAH, Hendry WF, et al. Treatment with gonadotrophin releasing hormone analogue in advanced prostatic cancer. $\mathrm{Br}$ Med $\mathcal{f} 1983$; 286:1309-12.

4 Walker KJ, Nicholson RI, Turkes A Plowman N, Blamey R. Therapeutic potential of the LH-RH agonist Zoladex (ICI 118630) in the treatment of advanced breast satellite symposium of the 7th international congress of endocrinology. $f$ Steroid Biochem 1984;20(6B):1408. (Abstract A90.)

5 Comite F, Pescovitz OH, Hench K, McNemar A, Loriaux DL, Cutler GB Jr. Therapy of precocious puberty: LHRH analogue effects on pubertal growth and maturation. Abstracts of satellite symposium of the 7 th international congress of endocrinology. F Steroid Biochem 1984;20(6B):1381. (Abstract

6 Kauli R, Pertzelan A, Ben-Zeer Z, et al. Treatment of precocious puberty with LHRH analogue in combination with cyproterone acetate-further experience. Clin Endocrinol $(O x f) 1984 \cdot \mathbf{2 0}: 377-87$.

7 Nillius SJ, Bergquist C, Wide L. Chronic treatment with the gonadotrophinreleasing hormone agonist $\mathrm{D}$-Ser $(\mathrm{TBu})^{6}-\mathrm{EA}^{10}-\mathrm{LRH}$ for contraception in women and men. Int $\mathcal{f}$ Fertil 1980;25:239-46.

8 Walker KJ, Nicholson RI, Turkes AO, et al. Therapeutic potential of the LHRH agonist, ICI 118630 , in the treatment of advanced prostatic carcinoma. Lancet $1983 ;$ ii : $413-5$

9 Furr BJA, Hutchinson FG. Treatment of rat mammary and prostatic tumour with the potent luteinising hormone releasing hormone (LHRH) analogue CI 118630. In: Proceedings of the 13th international congress of chemotherapy. Vienna 1983. Vienna: Verlar H Egermann, 1983:suppl:50-1. LH-RH analog ICI 118630 for the treatment of hormone responsive tumours.

Nature (in press).
11 Hutchinson FG, Furr BJA. Biodegradable polymers for the sustained release of

12 Anderson DC, Hopper BR, Lasley BL, Yen SSC. A simple method for the assay of eight steroids in small volumes of plasma. Steroids 1976;28:1018-24. halet SM, Beardwell CG, Morris Jones PH, Pearson D. Pituitary function after treatment of intracranial tumours in children. Lancet 1975; ii :104-7.

13a Clayton RN, Bailey LC, Cottam J, Arkell D, Perron TJ, Blackledge GRP. Radioimmuncassay for a GnRH agonist analogue in serum of patients with prostate cancer
Oxf) (in press)

14 Schally AV, Coy DH, Arimura A. LHRH agonists and antagonists. Int $f$

Gynaecol Obstet 1980;18:318-24.
15 Rivier C, Rivier J, Vale W. Chronic effects of (D-Trp ${ }^{6}$, Pro $\left.{ }^{9}-\mathrm{NEt}\right)$ luteinizing hormone-releasing factor on reproductive processes in the male rat. Endocrinology 1979;105:1191-1201.

16 Sundaram K, Connell KG, Bardin CW, Samojlik E, Schally AV. Inhibition of pituitary-testicular function with $\left(\mathrm{d}-\mathrm{Trp}^{6}\right)$ luteinizing hormone releasing

17 Resko JA, Belanger A, Labrie F. Effect of chronic treatment with a potent luteinizing hormone releasing hormone agonist on serum luteinizing hormone
and steroid levels in the male rhesus monkey. Biol Reprod 1982;26:278.

18 Kerle D, Williams G, Ware H, Bloom SR. Failure of long term luteinising hormone releasing hormone treatment for prostatic cancer to suppress serum luteinising hormone and testosterone. Br Med $\mathcal{f} 1984 ; 289: 468-9$.

19 Mann DR, Gould KG, Collins DC. Influence of continuous gonadotrophin releasing hormone $(\mathrm{G} n \mathrm{RH})$ agonist treatment on luteinizing hormone and testosterone secretion, the response to $\mathrm{GnRH}$, and the testicular response to human chorionic gonadotrophin in male rhesus monkeys. $f$ Clin Endocrinol Metab 1984;58:262-7.

20 Vickery $\mathrm{BH}$ McRae GI. Effects of continuous treatment of male baboons with superagonist of LHRH. Int f Fertil 1980;25:179.

Accepted 1 Nozember 1984 